YEARBOOK

of ANTITRUST

and REGULATORY

STUDIES

www.yars.wz.uw.edu.pl
Peer-reviewed scientific periodical, focusing on legal and economic issues of antitrust and regulation. Creative Commons Attribution-No Derivative Works 3.0 Poland License.

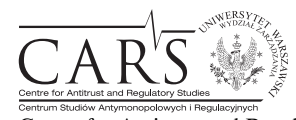

Centre for Antitrust and Regulatory Studies, University of Warsaw, Faculty of Management www.cars.wZ.uw.edu.pl

\title{
Access to Documents in Antitrust Litigation - EU and Croatian Perspective
}

\author{
by \\ Vlatka Butorac Malnar*
}

\section{CONTENTS}

I. Introduction

II. Access to documents and information from the Commission in cartelbased damages claims

1. Value of published decisions

1.1. Timing

1.2. Content

2. Access under Regulation $1 / 2003$

3. Access under the Transparency Regulation

4. Access under the Damages Directive

III. Access to documents and information in antitrust litigation under Croatian law

1. Access under the Competition Act

2. Access under the Act on the right of access to information

3. Possibilities and pitfalls of the pending implementation of the Damages Directive

IV. Conclusions

\section{Abstract}

The paper analyses access to documents in cartel-based damages cases from the EU and Croatian perspective. It considers all relevant EU and Croatian legislation and case-law primarily focusing on the expected impact of the newly enacted Damages Directive. It is argued that the new rules on access to documents provided by the Directive will not necessarily have a significant impact on damages proceedings following cartel decisions issued by the Commission. This is due to

* Ph.D., assistant professor, Faculty of Law, University of Rijeka, Croatia; vlatka@pravri.hr. 
the introduction of an absolute ban on the disclosure of leniency statements and settlement submissions via a 'maximum harmonization' rule. This conclusion is drawn from statistic figures showing that EU cartel enforcement rests solely on the leniency and settlement procedures. With that in mind, it is concluded that the Directive's general, permissive rules on access to documents (other than leniency and settlement procedures) will not be applicable in most damages cases following the cartel infringement decision issued by the Commission. However, it is also observed that the Damages Directive's new rules on access to documents may have the opposite impact on private enforcement in cases following infringement decisions issued by National Competition Authorities (NCAs) which do not rely as much on leniency in their fight against cartels as the Commission. The Directive's general rule on access to documents will apply in jurisdictions such as Croatia, where all of its cartel decisions so far have been reached within the regular procedure. It is argued that the general access rule, coupled with other rules strengthening the position of claimants in antitrust damages proceedings, might actually be beneficial for both public and private enforcement in such jurisdictions.

\section{Résumé}

Cet article analyse, de la perspective européenne et croate, la question d'accès aux documents dans les affaires concernant les actions en dommages introduites par les victimes des cartels. Il examine toute la législation et la jurisprudence européenne et croate, en se focalisant principalement sur l'impact attendu de la Directive relative aux actions en dommages récemment adoptée. Nous affirmons que les nouvelles règles sur l'accès aux documents prévues par la Directive ne vont pas avoir un impact significatif sur les actions en dommages introduites postérieurement à une décision de la Commission constatant une infraction. Cela est dû à l'interdiction absolue par une règle de « harmonisation maximale » de la divulgation des déclarations effectuées en vue d'obtenir la clémence et des propositions de transaction. Cette conclusion est tirée des informations statistiques qui montrent que la lutte contre les ententes repose uniquement sur les programmes de clémence et les procédures de transaction. En tenant compte de cela, il est conclu que des règles générales et permissives de la Directive concernant l'accès aux documents (autres que les procédures de clémence et de transaction) ne seront pas applicables dans la plupart des actions en dommages introduites après la décision sur la violation du droit de la concurrence rendue par la Commission. Cependant, il est également observé que des nouvelles règles sur l'accès aux documents introduits par la Directive peuvent avoir l'effet inverse sur l'application privée du droit de la concurrence dans les actions introduites après les décisions constatant l'infraction rendues par les autorités nationales de concurrence (ANC), qui ne comptent pas autant sur les programmes de clémence dans leur lutte contre les cartels, que la Commission. La règle générale de la Directive sur l'accès aux documents sera applicable dans les pays comme la Croatie, où l'ensemble des décisions constatant l'infraction du droit de la concurrence par un cartel, ont été jusqu'à maintenant atteint dans la 
procédure régulière. Nous affirmons que la règle générale sur l'accès aux documents, accompagnée d'autres règles renforçant la position des requérants dans les actions en dommages, pourrait être bénéfique à l'application publique et privée du droit de la concurrence dans telles juridictions.

Key words: EU Damages Directive; private enforcement; cartels; antitrust litigation; access to documents; access to file; evidence in antitrust litigation.

JEL: K23; K42.

\section{Introduction}

It has long since been established ${ }^{1}$ that efficient private enforcement of competition law is a vital complement to public enforcement ${ }^{2}$, both acting as prerogatives for the proper functioning of the EU internal market ${ }^{3}$. However, a study performed in 2004 found a 'total underdevelopment' ${ }^{4}$ of private antitrust enforcement in individual Member States. This finding was the source of the idea of introducing a specific, EU-wide regime that would facilitate private damages actions ${ }^{5}$. General procedural and substantive tort rules of the Member States proved to be unsuitable for effective antitrust litigation. With

1 The European Parliament proposed the idea of introducing rules on antitrust damages already in 1961 during the consultations on the European Commission's (EC) proposal for the first regulation on the application of articles 85 and 86 of the EEC (later becoming Regulation No. 17), OJ 1409, 15.09.1961, point 11.

2 There has been some academic debate over the desirability of private enforcement. See e.g. W.P.J. Wils, 'Should private antitrust enforcement be encouraged in Europe?' (2003) 26(3) World Competition 473. Wils argues that there isn't even a case for a supplementary role for private enforcement. For an opposite view see C.A. Jones, 'Private Antitrust Enforcement in Europe: A policy Analysis and Reality Check' (2004) 27(1) World competition 13-24.

3 'Both forms are part of a common enforcement system and serve the same aims: to deter anti-competitive practices forbidden by antitrust law and to protect firms and consumers from these practices and any damages caused by them. Private as well as public enforcement of antitrust law is an important tool to create and sustain a competitive economy'. Green Paper - Damages actions for breach of the EC antitrust rules \{SEC(2005) 1732\} COM/2005/0672 final, Section 1.1. (hereafter, Green paper). Along the same lines see e.g. speech delivered by the former EU Commissioner for Competition Policy Mario Monti entitled 'Private litigation as a key complement to public enforcement of competition rules and the first conclusions on the implementation of the new Merger Regulation' SPEECH/04/403.

4 Green Paper, Section 1.2.

5 For more see M. Bukovac Puvača, V. Butorac, 'Izvanugovorna odgovornost za štetu prouzročenu povredom pravila tržišnog natjecanja' (2008) 6 Zbornik radova Pravnog fakulteta Sveučilišta u Mostaru 249. 
the aim of changing this situation, and after a decade of legislative efforts, the long awaited Damages Directive was finally adopted in December 20146. The act covers substantive and procedural issues considered most important for the efficient functioning of the private enforcement regime. They include: access to evidence, limitation periods for bringing an action, standing, burden of proof, effect of decisions rendered by National Competition Authorities (hereafter, NCAs) and legal consequences of the passing-on of overcharges.

When the debate over the introduction of a specific private enforcement regime in the EU started, one important question arose. What is so specific about private antitrust enforcement that it requires specialized, tailor-made rules in order to enable injured parties to obtain damages suffered from competition law infringements? After all, each Member State had some form of its own tort legislation that worked quite efficiently for all other tort injuries. So what made competition-based claims so unusual? The most obvious, and maybe simplistic answer is the unpredictability of the outcome of high cost proceedings, caused by the complexity of antitrust litigation, coupled with inapt substantive and procedural rules for proving a claim. Both public and private antitrust proceedings require a very complex factual, legal and economic analysis. Economic evidence and sound reasoning are often needed to differentiate between pro-competitive and anti-competitive behaviour ${ }^{7}$. In order to reach its decision, a competition authority has to meet a high standard of proof based on a sophisticated analysis.

The same decision-making principles, methods and standards of proof should apply to courts in private antitrust litigation. Yet there are key differences between public and private enforcers when it comes to the availability of tools necessary to reach these analytical standards. Private claimants are generally much less likely to prove their case before a court ${ }^{8}$. This is due to a number of factors, some of which are purely procedural in nature.

${ }^{6}$ Directive 2014/104/EU of the European Parliament and of the Council of 26 November 2014 on certain rules governing actions for damages under national law for infringements of the competition law provisions of the Member States and of the European Union Text with EEA relevance, OJ L 349, 05.12.2014, p. 1.

7 Gutierrez-Rodriguez, Juan David, 'Expert Economic Testimony In Antitrust Cases: A Comparative Law And Economic Study' (2009) 14 International Law, Revista Colombiana De Derecho Internacional 224.

8 Particularly in stand-alone actions, as there is no prior administrative infringement decision on which the claimants' may rely in the civil proceedings. However, even in follow-on cases (cases brought after a competent competition authority has reached an infringement of EU competition rules decision), claimants are not in an envious position. Under most EU tort rules, claimants will still have to face great difficulties in proving causation, fault (where required) and quantifying damages. 
This paper will focus on a particular procedural issue - access to evidence in cartel cases. It is undoubtedly one of the most important components of the new private enforcement regime, as it potentially affects a great number of possible claimants. In fact, cartel activities are seen as the most harmful of all anti-competitive practices that result in the greatest number of injured subjects.

In order to make a plausible case, a private claimant has to produce evidence that supports his claim ${ }^{9}$ and collect data necessary for the provision of legal and economic proof in the courtroom ${ }^{10}$. However, antitrust litigation is characterized by an information asymmetry. While the infringer is in possession of all evidence pertaining to its illegal behaviour, the claimant often has nothing but the knowledge of the injury suffered. The evidence necessary to prove a damages claim is thus usually held by the infringer or by $3^{\text {rd }}$ parties, most notably a competition authority ${ }^{11}$. Evidence is generally not easily accessible to a private claimant, which is also insufficiently aware of the existence of such evidence ${ }^{12}$. It is thus crucial to look into the rules regulating access to documents for private claimants.

Section I of this paper analyses the available routes for a private claimant to obtain relevant information and documents from the European Commission (hereafter, Commission or EC) in preparation of a damages claim. The paper first scrutinizes the value of published EC decisions and points out to the possible problems facing private claimants (II.1). Access to documents via Regulation 1/2003 is examined next (II.2), followed by the Transparency Regulation (II.3), with the view of demonstrating their inefficiency for the purposes of damages actions. Rules on access to documents envisaged by the Damages Directive are last to be considered (II.4). It is argued that rules on access to documents contained in the Directive will not exercise a significant impact on damages proceedings following EC cartel decisions. This is due to the Commission's extensive use of the EU leniency programme and the settlement procedure, coupled with the Directive's very restrictive rules on the

${ }^{9}$ Some authors have questioned whether access to the file is really a prerequisite to assess damages. See C. Hummer, M. Cywinski, 'ECJ's Judgements In "Enbw" And "Donau Chemie" And The Unresolved Problems Of Access To File' (2014) 7(2) Global Competition Litigation Review 115-118.

10 'Access to information is critical to effective use of expert witnesses. Forensic economics depends upon access to firm-specific data. Often that data will relate to costs, markets, strategic planning and other matters that relate to the specific competition law offence at issue'; I.A. Gavil, 'The Challenges of economic proof in a decentralized and privatized European competition policy system: lessons from the American experience' (2008) 4(1) Journal of Competition Law and Economics 199.

11 Recital 15 of the preamble of the Damages Directive.

12 Recitals $14-15$ of the preamble of the Damages Directive. 
disclosure of documents obtained by the EC in such proceedings. Here, private enforcement will remain a subsidiary tool to public enforcement, rather than its complement. It is argued furthermore that differences between national rules on access to documents will continue to persist albeit to a minor degree.

Section III focuses its assessment on the case of Croatia, considering to what an extent private enforcement will become efficient following cartel decisions rendered by smaller NCAs (which do not rely as much on leniency in their fight against cartels as the Commission). To that end, rules on access to documents under existing Croatian legislation are analyzed, considering the normative set-up of the Civil Procedure Act (III), the application of the Competition Act (III.1), and followed by the Act on the right of access to information (III.2). Last but not least, possibilities and pitfalls of the pending implementation of the Damages Directive are considered (III.3). It is argued that because the Croatian Competition Agency does not relay as much on leniency as the Commission, the Directive's general, more permissive rule on access to documents will apply here. Hence, the implementation of the Directive might prove beneficial for both public and private enforcement in Croatia.

\section{Access to documents and information from the Commission in cartel-based damages claims}

\section{Value of published decisions}

A full-length decision of the Commission on an antitrust violation may prove to be a valuable source of information for private claimant. It may contain information directly pertinent to a damages claim, or may be used as guidance for identifying information and documents to be requested from the EC for the purpose of a damages procedure. Most useful are documents obtained during the preparation of a damages claim, when the claimants can evaluate the risks associated with initiating litigation, and 'take account of evidence and findings when drafting pleadings' 13 . Before commencing a civil damages procedure, a future claimant may want to wait until the EC publishes a full-length infringement decision because of its potential evidentiary value. However, a claimant will have to take into consideration several likely impediments.

13 A. Howard, 'Disclosure Of Infringement Decisions In Competition Damages Proceedings: How The UK Courts Are Leading The Way Ahead Of The Damages Directive' (2015) 6(4) Journal Of European Competition Law And Practice 257. 


\subsection{Timing}

First, it may take years before a full-length decision is publicly available. It has become common practice for the Commission to publish in the Official Journal $^{14}$ summary decision only ${ }^{15}$. A full, non-confidential version of the decision is usually published on the Commission website with a delay ${ }^{16}$. The latter occurs due to disputes arising between the EC and the parties concerning the contents of the web publication ${ }^{17}$, particularly with respect to the question what information deserves confidential treatment.

When deciding on the disclosure of allegedly confidential information, the Commission must follow a rather complicated and lengthy procedure as described by the Court in the $A K Z O I^{18}$ judgement ${ }^{19}$. The delay may be even more significant in cases where the EC refuses to grant confidentiality to particular pieces of information. This can result in the interested party applying, pursuant to Article 278 TFEU, for interim relief before the General Court (hereafter, GC) on the ground of confidentiality ${ }^{20}$. Cartel infringers may tactically take advantage of this right to prolong the 'push-back exercise

14 According to Art. 30 Regulation 1/2003, the EC is obliged to publish in the Official Journal only the names of the parties and the main content, including any penalties imposed.

15 P. Roth, V. Rose (eds.), Bellamy \& Child, European Community Law of Competition, 6th ed., Oxford University Press 2008, para 13.112.

16 Regulation 1/2003 does not specify publication time limits. While the EC does its best to publish simultaneously the summary decision in the Official Journal and the full non-confidential version on its website, the later is often delayed. This in turn may lead to a substantial publishing delay 'due to disputes with the parties regarding the contents of the web publication'. European Commission, Antitrust manual of procedure, Internal DG Competition working documents on procedures for the application of Articles 101 and 102 TFEU, March 2012, available at http:// ec.europa.eu/competition/antitrust/antitrust_manproc_3_2012_en.pdf (accessed 07.05.2015), Ch. 28 Publication of decisions, p. 3. (hereafter, Antitrust manual of procedure).

17 Antitrust manual of procedure, Ch. 28 Publication of decisions, p. 3.

18 AKZO Chemie BV and AKZO Chemie UK Ltd v Commission, Case 53/85, EU:C:1986:256, para 29.

19 'Akzo procedural rule says that where the Commission intends to disclose information which the company providing it wants to be treated as business secret or confidential, it shall inform that company in writing of its intention and the reasons for it. Where the company concerned objects to the disclosure of this information, but the Commission finds that the information is not protected and may therefore be disclosed, that finding shall be stated in a reasoned decision. This decision has to be notified to the company concerned, which has to be given the opportunity to bring an action before the European Court of First Instance with a view to having the Commission's assessments reviewed. The information may not be disclosed before one week after the decision has been notified'. Glossary of competition terms, AKZO procedure, available at http://www.concurrences.com/ Droit-de-la-concurrence/Glossaire-des-termes-de/AKZO-Procedure?lang=en (accessed 11.05.2015).

${ }^{20}$ See Bank Austria Creditanstalt v Commission; Pergan Hilfsstoffe für industrielle Prozesse v Commission; Pilkington v Commission; Akzo v. Commission 
to restrain publication which may extend beyond the limitation periods and force claimants to issue half-baked claims which then face the risk of strike out or summary judgement' 21 . With this strategy in mind, battles concerning information disclosure (in the fuller non-confidential version of the Commission's decision) have recently moved into the courtroom arena, as demonstrated in Pilkington ${ }^{22}$ and most recently $A K Z O^{23}$ judgments. In both cases, the infringers were granted interim relief against the publication of an extended version of a Commission decision that potentially contained data valuable for private claimants.

According to Article 104(2) of the Rules of Procedure, an application for interim measures must state the subject-matter of the proceedings, the circumstances giving rise to urgency, and the pleas of fact and law establishing a prima facie case for the requested interim measures. Where appropriate, the judge hearing the application must also weigh up the interests involved ${ }^{24}$.

For parties resisting publication of a fuller version of an infringement decision, the recipe for obtaining interim relief seems to be rather simple. It is practically enough for an applicant to bring before the court an action for the annulment of the EC decision (that denies the request for confidential treatment) simultaneously with an application for interim measures.

In both Pilkington and $A K Z O$, the argument essentially evolved around the conclusion that the applicants were likely to suffer serious and irreparable harm because, if the information was disclosed, they would be denied effective judicial protection before the resolution of the main action. If the interim measures were denied, the EC would be free to immediately publish the extended version of its infringement decision. This would, in turn, render any subsequent judgments ordering its annulment an illusion by depriving it of its effectiveness. By having access to such arguably confidential information, the general public would have the opportunity to use it as they please. The eventual subsequent annulment of the infringement decision would not be able to reverse these consequences.

As a result, when an application for interim measures is accompanied by an action for the annulment of a Commission decision denying a request for confidential treatment, the interim measure is likely to be granted, in order not to prejudice or render illusionary the subsequent annulment procedure (unless, of course, the information is clearly non-confidential). This back and forth battle between the applicants and the Commission will almost always delay the publication of an EC infringement decision and this fact is to be

\footnotetext{
21 A. Howard, supra note 13 at 258.

22 Pilkington v Commission, T-72/09, EU:T:2014:1094.

23 Akzo Nobel NV and Others v European Commission, T-345/12, EU:T:2015:50.

${ }^{24}$ Order of the President in Case C-445/00 R Austria v Council [2001] ECR I-1461, para 73.
} 
taken into account by private litigants. The Commission will thus generally have to limit the information contained in its summary decision to basic facts only, while a more complete publication will have to await the conclusion of the main proceedings before the $\mathrm{GC}^{25}$. Even if infringers may successfully avail themselves of the rules concerning interim relief to delay the publication of a full infringement decision, this by no means implies that they will be equally successful in the main proceedings for the annulment of the decision refusing to grant confidential treatment. As much as it is useful to have the complete decision at the pre-action stage, in order not to face limitation problems, it is much more efficient to initiate private claims and then request the stay of such proceedings awaiting the publication of a full EC decision.

\subsection{Content}

Private litigants should bear in mind that sometimes even the full versions of an EC decision might still lack the information and data necessary for the claimant to find evidence necessary to prove his claim. This is particularly true in cartel cases investigated and fined through settlement and leniency procedures. Generally, such decisions are very sparse when it comes to the facts of the case and the economic data pertaining to the cartel behaviour, this is true in particular for settlement procedures. Moreover, access to materials obtained by the EC in leniency and settlement proceedings has now been subjected to sever restrictions by the new disclosure rules contained in the Damages Directive.

However, in the $A K Z O$ v. Commission ${ }^{26}$ judgment rendered in January 2015, the GC extended the possible publishable content of full non-confidential versions of cartel decisions taken in the ambit of a leniency procedure.

The dispute arose when the Commission, for reasons of transparency, decided to publish another, fuller version of its infringement decision concerning the hydrogen peroxide cartel ${ }^{27}$. The extended version was supposed to include extracts from leniency materials describing the way in which the cartel operated. This would include details on the collusive contracts and anticompetitive agreements, names of products concerned, figures concerning prices, allocation of market shares and objectives pursued by the cartel. Referring to the EC's duty to honour the legitimate interests of undertakings in protecting their business secrets, the parties opposed the publication of

25 M. Kellerbauer, 'The Recent Case Law On The Disclosure Of Information Regarding EU Competition Law Infringements To Private Damages Claimants' (2014) 35(2) European Competition Law Review 60.

26 Judgement $A K Z O$ v. Commission, T-345/12, EU:T:2015:50.

27 EC decision, Hydrogen Peroxide and Perborat (COMP/F/38.620) of 03.05.2006. 
the extended version of the infringement decision. When the Hearing Officer rejected one of the undertaking's (AKZO) request for confidential treatment, AKZO sought the protection of the GC by initiating proceedings against the Commission. The court applied a test developed in settled case law whereby in order to be considered confidential, the information must be: (i) known only to a limited number of persons; (ii) if disclosed, it must be liable to cause serious harm to the person who has provided it or to $3^{\text {rd }}$ parties and, finally, (iii) the interests liable to be harmed by the disclosure are, objectively, worthy of protection. In essence, the Court held that the EC is entitled to publish an extended version of its cartel decision containing a description of the constituent elements of the infringement. Such publication can take place even if it is likely to cause AKZO serious harm because it is able to facilitate damages claim against AZKO. The court ruled that being exposed to an increased risk of civil liability is not a cartel participant's legitimate interest that needs to be protected.

This judgment shines new light on the value of published leniency-based cartel decisions for private litigants in terms of the information they contain. The ruling may be seen as a compromise, or a balance between public and private enforcement. This is so particularly in light of the restrictive normative developments brought forward by the Damages Directive regarding access to leniency materials. If leniency corporate statements enjoy full protection, the rest of leniency materials do not necessarily fall into the category of confidential information. They are thus to be disclosed (though the publication of the decision) to as many persons as possible regardless of the harm that may cause to the infringers in terms of an increased risk of civil liability.

Although this judgement is more favourable to private litigants' interests, information contained in published decisions will hardly ever be sufficient to meet the standard of proof necessary to demonstrate a damages case. Access to documents is thus an inevitable step for a claimant. The latter may seek to obtain the confidential version of the EC decision, or may try to seek information and documents contained in the file of the Commission. The EC's file contains a 'plethora of useful information pertaining to sales volumes, prices, internal company documents (such as marketing strategies and e mail), commercial relationships with other parties and all important leniency documents and corporate statements ${ }^{28}$. These documents will remain valuable even in follow-on cases where it is not necessary to prove the existence of the antitrust violation. Such information could be useful in proving the extent of the harm suffered and the causal link between the violation and the harm.

28 P. Bentley, D. Henry, 'Antitrust Damages Actions: Obtaining Probative Evidence In The Hands Of Another Party' (2014) 37(3) World Competition 274. 
Prior to the enactment of the Damages Directive, parties had at their disposal two main routes for obtaining the necessary information and documents from the EC: 1 ) the route of Regulation $1 / 2003^{29}$ and the route of 2 ) the Transparency Regulation ${ }^{30}$. These two instruments remain a valid legal ground for obtaining documents in the possession of the EC even after the enactment of the Damages Directive ${ }^{31}$. However, considering the development of EU case law on the application of these two instruments and, in particular, on the use of the Transparency Regulation ${ }^{32}$, they may not be as attractive a tool for these purposes as they used to $b^{33}$.

\section{Access under Regulation $1 / 2003$}

Pursuant to Article 15(1) of Regulation 1/2003, Member States' courts may request, in proceedings for the application of Article 101 and 102 TFEU, the EC to provide them with information or opinions on questions concerning the application of EU competition rules ${ }^{34}$. A detailed explanation of this duty is contained in the Notice on the co-operation between the Commission and the courts of the EU Member States in the application of Articles 101 and 102 TFEU (hereafter, Notice on cooperation) ${ }^{35}$. Accordingly, information held by the EC may refer to both documents in its possession and information of

29 There may be other routes to obtain access to documents such as seeking disclosure before non-EU courts through discovery rules applicable in that jurisdiction; applying to be interveners before EU courts in appeal proceedings; attempting to act as a complainant before the EC or NCAs. For more see G. De Stefano, 'Access of damage claimants to evidence arising out of EU cartel investigations; a fast evolving scenario' (2012) 5(3) Global Competition Litigation Review 95-110.

30 Regulation (EC) No. 1049/2001 of the European Parliament and of the Council of 30 May 2001 regarding public access to European Parliament, Council and Commission documents, OJ L 145, 31.05.2001, p. 43.

31 In fact, Article 6(2) of the Damages Directive explicitly states that rules on disclosure of evidence included in the file of a competition authority are without prejudice to rules and practices under the Transparency regulation. Furthermore, recital 15 of the preamble of the Damages Directive states that where a national court wishes to order disclosure of evidence by the EC, Article 15(1) of the Regulation 1/2003 applies.

32 See Commission v. EnBW, C-365/12 P, EU:C:2014:112.

33 Because the differences disfavour claimants litigating in one Member State as compared to claimants litigating in another member state. See e.g. P. Bentley, supra note 28 at 273; M. Kellerbauer, supra note 25 at 57.

${ }^{34}$ Information held by the EC may refer to both documents in its possession and information of a procedural nature.

35 Notice on the co-operation between the Commission and the courts of the EU Member States in the application of Articles 81 and 82 EC, OJ C 101, 27.04.2004, p. 54 (hereafter, Notice on co-operation). 
a procedural nature ${ }^{36}$. However, the Commission's disclosure duty is limited. Since the EC is bound by professional secrecy, it may provide national courts with information only if the latter provide a guarantee that the confidential information and business secrets will remain protected while under their care ${ }^{37}$.

Furthermore, the Commission may refuse to grant access to the requested information in order to safeguard the interests of the EU, its functioning and independence ${ }^{38}$. On these grounds, the EC can reject a national court's request for the delivery of information submitted by leniency applicants. According to the Notice on the co-operation, such information may be granted only with the consent of the leniency applicants ${ }^{39}$. In practice, however, this solution works like an absolute ban on the disclosure of corporate statements, since no leniency applicant would grant access to documents that will be used against it in a civil procedure ${ }^{40}$. Considering the impossibility of access to documents held in the EC's files through Article 15 of Regulation 1/2003, $3^{\text {rd }}$ parties may take advantage of the Transparency Regulation to obtain evidence from the Commission.

\section{Access under the Transparency Regulation}

Another way to access the files of the EC is through the application of general rules on access to documents of EU institutions provided by the Transparency Regulation. The purpose of this act is to facilitate access to documents of all EU institutions, including the Commission. The Transparency Regulation is a general tool not designed specifically for antitrust litigation. It is also a public tool - available to any individual or corporation residing or having their headquarters in a Member State. Furthermore, unlike Regulation 1/2003, the Transparency Regulation does not condition access upon a particular use

36 According to point 21 of the Notice on the co-operation, a national court may ask the $\mathrm{EC}$ for documents in its possession or for information of a procedural nature to enable it to discover whether a certain case is pending before the EC, whether the latter has initiated a procedure or whether it has already taken a position. A national court may also ask the $\mathrm{EC}$ when a decision is likely to be taken, so as to be able to determine the conditions for any decision to stay proceedings or whether interim measures need to be adopted.

37 Recital 25 of the Notice on co-operation.

38 Recital 26 of the Notice on co-operation.

39 Recital 26 of the Notice on co-operation.

40 This right of leniency applicants will not relate to pre-existing documents - 'documents not specifically drawn up for the leniency application but submitted as evidence to the Commission as a part of a leniency application'; S.V. Walle, Private Antitrust Litigation in the European Union and Japan: A Comparative Perspective, Maklu, Antwerpen-Apeldoorn 2013. p. 195. 
of the accessed document. In other words, documents obtained through the Transparency Regulation may be used for any purpose.

Because of these distinct features, access to documents via the Transparency Regulation is subject to exceptions - some of which have been very successfully invoked by the Commission when resisting the disclosure of leniency statements and settlement submissions. According to Article 4(2) of the Transparency Regulation, the Commission may refuse, inter alia, access to a document where disclosure would undermine the protection of commercial interests of a natural or legal person, or the purpose of inspections, investigations and audits, unless there is an overriding public interest in disclosure. The EC used to consistently invoke these exceptions through 'blanket' disclosure refusals covering entire categories of documents ${ }^{41}$. Its protective attitude towards leniency submissions is very explicitly stressed in the Leniency Notice ${ }^{42}$ stating that the 'Commission considers that normally public disclosure of documents and written or recorded statements received in the context of the leniency application would undermine certain public or private interests, for example the protection of the purpose of inspections and investigations, within the meaning of Article 4 of Regulation (EC) No 1049/2001 even after the decision has been taken'43.

Initially, in cases where private parties tried to annul decisions of the EC refusing access to its file, EU courts interpreted the exceptions of Article 4(2) of the Transparency Regulation rather narrowly, taking a claimant-friendly approach. Already in 2005, in Austrian Banks case ${ }^{44}$, the GC ruled that the 'blanket refusal' approach taken by the $\mathrm{EC}$ is unlawful ${ }^{45}$. A similar conclusion was reached in the 2011 CDC hydrogen peroxide case $^{46}$.

The $C D C$ hydrogen peroxide case involved a party's request to access a single document, the index of the case file held by the Commission. It was a valuable document as it listed all items collected in the file, and would enable the private litigant to identify specific pieces of evidence for which disclosure should be requested in already initiated damages proceedings. When the Commission ultimately decided to disclose only a non-confidential version of the 'statement of contents', the disclosure-seeking party initiated proceedings

41 Ibidem, 192.

42 Commission notice on immunity from fines and reduction of fines in cartel cases, OJ C 298, 08.12.2006, p. 17. (hereafter, Leniency notice).

43 Para 40 of the Leniency notice.

${ }^{44}$ VereinfürKonsumenteninformation $v$ Commission of the European Communities, T-2/03, EU:T:2005:125.

45 For a more detailed comment see G. Mackenzie, 'The public now enjoys partial access to the EC's file in cartel cases' (2005) 4(9) Competition Law Insight 8-9.

${ }^{46}$ CDC Hydrogene Peroxide Cartel Damage Claims (CDC Hydrogene Peroxide) v European Commission T-437/08, EU:T:2011:752. 
before the GC. The latter ruled against the EC - it ordered the index to be disclosed, arguing that this would not undermine the protection of business secrets or the purpose of the investigation. The GC expressed the view that avoiding private damages actions cannot be regarded as a commercial interest of a cartel participant, and particularly not an interest deserving of public protection.

As to the protection of the purpose of the investigation, the GC ruled that this concept cannot be interpreted by the Commission as including all of its policy in regard to cartel punishment and prevention. As a result, the EC may not refuse disclosure of all documents related to its leniency programme on the basis of the argument that such disclosure may in the future discourage cartel infringers from co-operating with the Commission ${ }^{47}$. Such a broad interpretation of the concept of 'investigation activities' was deemed by the $\mathrm{GC}$ as incompatible with the principle of the fullest possible effect of the right of public access to documents entrenched in the Transparency Regulation ${ }^{48}$.

In February 2014, the Court of Justice ruled on the $E n B W$ case $^{49}$ limiting access to documents as defined by the GC in $C D C$ and adopted a strict attitude towards disclosure, as it previously did in Netherlands v. Commission ${ }^{50}$.

The EnWB case started when private litigants sought access to practically the entire EC's file. The latter denied such access and the parties sought the annulment of this decision before the GC. The Court ruled that the EC has to inspect every single document requested before refusing access and thereby annulled its 'blanked refusal' approach. The Commission appealed the GC judgement and in February 2014, the Court of Justice set aside the $1^{\text {st }}$ instance ruling. In essence, the Court of Justice stated that authorising generalised access to a leniency file on the basis of the Transparency Regulation would jeopardise the balance formulated in Regulation 1/2003 and 773/200451. In other words, the balance between the undertakings' obligation to submit sensitive commercial information to the EC and the EC's duty to protect such information on the grounds of professional and business secrecy.

The Court concluded, inter alia, that in order to apply the exceptions of Article 4(2) of the Transparency Regulation, the EC is entitled to assume that disclosure of documents will, in principle, undermine a) the protection of the commercial interests of the undertakings involved, and b) the purpose

47 Ibidem, paras 68-69.

48 Ibidem, para 71.

49 European Commission v EnBW Energie Baden-Württemberg AG, C-365/12 P, EU:C:2014:112.

50 Kingdom of the Netherlands $v$ European Commission, T-380/08, EU:T:2013:480.

51 According to these acts, cartel infringers are under the duty to submit sensitive commercial information, while the EC in turn guarantees their increased protection, by virtue of the requirement of professional secrecy and business secrecy (ibidem, para 93). 
of the investigations relating to the proceeding. Such presumption may be reached without carrying out a specific, individual examination of each of the documents in the file ${ }^{52}$. The Court of Justice stated also that this general presumption is rebuttable by demonstrating that a specific document's disclosure is not covered by the presumption, or that there is an overriding public interest in disclosure ${ }^{53}$. According to the Court of Justice, there is no need for every document in the cartel file to be disclosed for the purposes of actions for damages. Accordingly, a private claimant should establish that access to the EC's cartel file is necessary for him, in order to enable the Commission to perform the weighing-up of the interests in favour of disclosure against those in favour of confidentiality. In this concrete case, the Court of Justice held that the EC was right in denying access as there was nothing in the given case that was capable of rebutting the described presumption. The fact that EnWB intended to seek compensation for the loss allegedly caused by the cartel did not suffice to obtain disclosure. According to the Court, the interest in obtaining compensation for the loss suffered cannot constitute an overriding public interest within the meaning of Article 4(2) of the Transparency Regulation ${ }^{54}$. Instead, the claimant has to show in what way access to documents is necessary, that is, demonstrate that disclosure would enable it to obtain the evidence needed to establish its claim for damages. The claimant would also have to demonstrate that there are no other ways of obtaining that evidence. According to the Court of Justice, EnWB failed to do $\mathrm{so}^{55}$.

The finding of the Court of Justice makes it much harder for the claimants to obtain documents contained in a cartel file via the Transparency Regulation ${ }^{56}$. They have to establish that a specific document is necessary for them to establish the damages claim and that there are no other ways to obtain that evidence ${ }^{57}$. By contrast, the Commission has a much easier task as it does not have to weigh up interests of access with the interest of

52 Ibidem, para 93. As to the latter, the Court concluded that, investigations relating to the proceeding may be regarded as completed only when the decision adopted by the EC in connection with that proceeding is final.

53 Ibidem, para 100.

54 Ibidem, paras 104-106.

55 Ibidem, para 132.

56 For a more detailed comment on the case see C. Lacchi, A. Östlund, 'General Presumptions of Non-disclosure of Leniency Documents: a New Approach to the Interaction between Public and Private Enforcement of Antitrust Law?' (2014) European Law Reporter 56-61; A. Blume Huttenlauch, 'Transparency (Un)limited?' (2014) European Law Reporter 107-109; B. Lebrun, L. Bersou, 'Commission v EnBWEnergie: Non-Disclosure of Leniency Documents' (2014) 5(7) Journal of European Competition Law \& Practice 462-463.

57 Kingdom of the Netherlands v European Commission, T-380/08, EU:T:2013:480, para 132. 
confidentiality for each document in the file. It may instead rely on the general presumption that disclosure may jeopardize interests protected by antitrust rules $^{58}$. After this ruling, ' $[\mathrm{t}]$ he door to having sight of Commission documents under Transparency Regulation may therefore have been effectively closed, or at least left only slightly ajar'59. In practice, all hopes to obtain evidence necessary to prove damages claim reside with the Damages Directive.

\section{Access under the Damages Directive}

Until the enactment of the Damages Directive, there was no specific EU-wide regime on disclosure of evidence in antitrust litigation. In order to access the files of the Commission, private claimants relied on either Regulation 1/2003 or the Transparency Regulation, both with very limited success. When it comes to access to documents contained in the files held by NCAs, private litigants had to rely on varying national procedural rules. National laws on disclosure of evidence differ greatly among Member States. While the UK, with its common-law system, provides for a wide disclosure through general discovery rules, Member States belonging to the civil-law family do not have such standard procedures and consequently have a much more limited scope of evidence disclosure. These differences in national laws are "conductive to forum shopping, which is an anathema of the principles underpinning the single market' ${ }^{60}$. This fact alone was inductive to the creation of an EU-wide disclosure regime in actions for damages resulting from breaches of EU competition rules. However, it is yet to be seen whether the Damages Directive will result in the desired level of harmonization of national rules on access to documents, completely eliminating forum shopping incentives.

The Damages Directive introduces a specific disclosure regime considered to be its 'most controversial initiative' 61 . According to the Damages Directive, parties are supposed to have easier access to evidence which they need for the purposes of proving their damages claim, while avoiding overly broad disclosure of evidence. Very much in line with the judgement in the EnWB case, the Damages Directive emphasises that it is implausible that all evidence contained in the EC's file will be needed for the action for damages. Accordingly, in order to safeguard the effective protection of the right to

58 http://www.stibbe.com/en/news/2014/march/competition-law-newsletter---march-2014 (accessed 14.05.2015).

59 P. Bentley, supra note 28 at 276.

${ }^{60}$ Ibidem, 272.

61 A. Howard, supra note 13 at 256. 
compensation, it is unnecessary for every single document concerning EC proceedings to be revealed to a claimant merely because he is planning an action for damages ${ }^{62}$. Thus, subject to the principles of effectiveness ${ }^{63}$ and equivalence ${ }^{64}$, a party in need of documents held by the opposing party or a $3^{\text {rd }}$ person, including the competition authority, might as a rule, obtain a court order for the disclosure of those documents ${ }^{65}$.

This general rule of disclosure prescribed by Article 5 of the Damages Directive is conditioned upon several factors. To begin with, disclosure is available only to a claimant who demonstrates that he has suffered harm as a result of the given antitrust infringement. A claimant may do so by presenting a reasoned justification based on reasonably available facts and evidence showing plausibility of his claim. Furthermore, disclosure may be granted only for specified items of evidence, or relevant categories of evidence, specified as precisely and narrowly as possible to avoid 'fishing expedition' 66 . Although it is a legitimate objective to avoid overly broad disclosure, it will still be difficult for claimants to narrowly identify those documents which they believe to be in the possession or control of the defendant, a $3^{\text {rd }}$ party or a competition authority ${ }^{67}$. In addition, national courts have wide discretion in deciding whether documents so specified are proportionate to the defendant's legitimate interests. In fact, national courts may only order disclosure of evidence provided it is proportionate. In deciding which specific evidence, or group of evidence, is proportionate, national courts will consider the legitimate interests of all parties concerned and several additional factors: the extent to which the claim or defence is supported by available facts and evidence; the

62 Recital 22 of the preamble of the Damages Directive.

${ }^{63}$ In accordance with the principle of effectiveness, Member States must ensure that all national rules and procedures relating to the exercise of damages claims are designed and applied in such a way that they do not render practically impossible, or excessively difficult, the exercise of the EU right to full compensation for harm caused by an antitrust infringement (Art. 4(1) of the Damages Directive).

${ }^{64}$ In accordance with the principle of equivalence, national rules and procedures relating to damages actions resulting from Article 101 or 102 TFEU breaches must not be less favourable to the alleged injured parties than those governing similar damages actions resulting from infringements of national law (Art. 4(2) of the Damages Directive).

65 Art. 5(1) of the Damages Directive.

66 According to Recital 23 of the preamble of the Damages Directive, these are non-specific or overly broad searches for information unlikely to be of relevance for the parties to the proceedings. Accordingly, generic disclosure of documents in the file of a competition authority relating to a certain case, or the generic disclosure of documents submitted by a party in the context of a particular case, should not meet the proportionality criteria.

67 A. Howard, 'The Draft Directive On Competition Law Damages - What Does It Mean For Infringers And Victims?' (2014) European Competition Law Review 53. 
scope and cost of disclosure ${ }^{68}$; and the existence of confidential information ${ }^{69}$. These general principles and rules may be broadened up by Member States in favour of wider disclosure.

However, according to the Damages Directive, the general rule on disclosure has two important exceptions directly affecting claimants who suffered damages as a consequence of a cartel. Article 6 sets out a rule of absolute protection of leniency statements and settlement submissions and a temporary ban for certain categories of evidence - the ban is applicable until the end of the administrative procedure underway before a competition authority ${ }^{70}$. The latter relates to settlement submissions that have been withdrawn and information prepared specifically for the purpose of public competition law proceedings, such as statement of objections or parties' submissions to a competition authority ${ }^{71}$. The disclosure of evidence in the file of a competition authority that does not fall within the ban (absolute or temporary) - so-called pre-existing documents - may be disclosed at any time. Finally, according to the Damages Directive, evidence is to be obtained from a competition authority only when it cannot reasonably be obtained from another party or a $3^{\text {rd }}$ party ${ }^{72}$. In order to be granted access, the party should first demonstrate that it is reasonably unable to obtain documents from other sources. This may prove to be an additional hurdle to be overcome before accessing the EC's file.

The general rule on access to documents contained in the Damages Directive is a 'minimum harmonisation' rule, as it sets only the minimum standard and permits Member States to implement a wider disclosure of evidence, provided the principle of proportionality is observed. Given this wide discretion given to Member States, and the interpretative discretion of national judges, the level of success of collecting evidence on the basis of this general rule will depend mostly on the implementation of this article into each national legal order and the use of court powers to order disclosure. For this reason, differences may persist across Member States even in the future and the envisaged harmonisation will not be sufficient to entirely annul forum shopping incentives on account of disclosure rules. By contrast, the aforementioned exception to the

${ }^{68}$ Especially for any $3^{\text {rd }}$ parties concerned, including preventing non-specific searches for information which is unlikely to be of relevance for the parties in the procedure (Art. 5(3)(b) of the Damages Directive).

${ }^{69}$ Especially concerning $3^{\text {rd }}$ parties in the procedure and what arrangements are in place for protecting such confidential information (Art. 5(3)(c) of the Damages Directive).

70 That exemption should also apply to verbatim quotations from leniency statements or settlement submissions included in other documents; Recital 26 of the preamble of the Damages Directive.

71 Art. 6(5) of the Damages Directive.

72 Recital 26 of the preamble of the Damages Directive. 
general disclosure rule covering leniency statements and settlement procedures is a rule of 'maximum harmonisation'. Member State may thus not deviate from this rule, that is, they are not allowed to implement a different solution domestically to that prescribed in the Directive. This means that all national laws implementing it will have to ban the disclosure of leniency statements and settlement submissions. With this in mind, the effect of the rules on access to documents envisaged by the new Damages Directive will depend largely on the extensiveness of the use of leniency and settlements by given competition authorities in their fight against cartels.

The described regulatory solution of the Damages Directive only appears to strike the right balance between private and public enforcement. It has to be argued here that the new rules will not have the expected beneficial impact on those damages proceedings that following EC cartel decisions, because the Commission relies almost exclusively on leniency procedures and settlement submissions in its cartel cases. When it came to the design of the Damages Directive, the interests of public enforcement prevailed over the interests of private enforcement with respect to cartels. Adopting a maximum harmonisation rule providing for an absolute ban of access to evidence obtained within leniency and settlement procedures is a clear indication thereof. This explicit policy choice is justified by the key importance of leniency and settlements for the fight against cartels. In fact, recital 26 of the Damages Directive expressly states that 'leniency programmes and settlement procedures are important tools for the public enforcement of Union competition law as they contribute to the detection and efficient prosecution of, and the imposition of penalties for, the most serious infringements of competition law'. Furthermore, it essentially states that effective leniency and settlement procedures are beneficial to damages actions as most of those claims follow-on from leniency and settlement decisions. While this is true in terms of exposing illegal cartel behaviour, it is very difficult to see in what other way are these procedures beneficial to private claimants, particularly considering the very low evidentiary value of settlement decisions. Finally, the legislator argues that 'undertakings might be deterred from cooperating with competition authorities under leniency programmes and settlement procedures if self-incriminating statements such as leniency statements and settlement submissions, which are produced for the sole purpose of cooperating with the competition authorities, were to be disclosed'. According to the Damages Directive, such disclosure would place cooperating undertakings in a worse position than non-cooperating undertakings in terms of an increased risk of exposing them to civil and/or criminal liability ${ }^{73}$. Even if this proposition is

73 Recital 26 of the preamble of the Damages Directive. 
true, rules against disclosure should not have the impact of extending the 'immunity from fines under an administrative leniency to civil (non-) liability before the judiciary' 74 .

The Damages Directive tries to compensate the absolute ban on the disclosure of leniency statements and settlement submissions by making 'preexisting information' available. This category contains evidence that exists irrespective of the proceedings of a competition authority, whether or not such information is in the file of a competition authority ${ }^{75}$. In other words, even if a prohibition decision is rendered through the leniency procedure, only leniency statements are fully protected from disclosure ${ }^{76}$. Hence, all other materials gathered by a competition authority prior to the leniency application, or material existing independently from such an application, are available for disclosure (such as e-mails between cartel participants). By a verbatim of the Damages Directive, these should include even original documents and information quoted in leniency statements or attached to such statements. According to recital 28 of the Damages Directive, national courts should be able, at any time, to order the disclosure of such information.

In a press release following the enactment of the Damages Directive, the Commission stressed that evidence needed by claimants will typically be contained in such documents ${ }^{77}$. Nonetheless, it is doubtful whether such information will be sufficient to prove damages claims in all cases ${ }^{78}$. Even where such documents would provide sufficient proof for the claimant, the latter would face difficulties in exactly pinpointing such documents or information. This is so given the requirement of the Damages Directive that disclosure may be ordered only for specified items of evidence, or relevant categories of evidence, circumscribed as precisely and narrowly as possibly. If a claimant asked for a category of evidence named 'pre-existing documents', this would be considered too broad of a request and it would be regarded as a fishing

74 A. Chirita, 'The disclosure of evidence under the Directive 2014/104/EU', (not published yet) presented and prepared for the 4. Petar Šarčević International Scientific Conference: EU Competition And State Aid Rules: Interaction Between Public And Private Enforcement, Rovinj, 9-10 April 2015.

75 Art. 2(17) Damages Directive.

76 Art. 2(16) Damages Directive explicitly excluded pre-existing information from the definition of a leniency statement.

77 EC Memo: Antitrust: Commission proposal for Directive to facilitate damages claims by victims of antitrust violations - frequently asked questions, Brussels, 17 April 2014, available at http://europa.eu/rapid/press-release_MEMO-14-310_en.htm

78 C. Brömmelmeyer, 'Directive damages: Does the commission overstep the marks again?' (2015) 1 Sorbonne Procedural Law Review Online, available at http://irjs.univparis1.fr/labo/departement-de-recherche-justice-et-proces/revuelectroniqueliensprocessu/ directiveprivateenforcement/ (accessed 10.07.2015). 
expedition on the side of that claimant. A disclosure motion for such a category of evidence would thus most likely be rejected by the court. Furthermore, it should be stressed that pre-existing documents are often encrypted and basically useless, unless explained by the defendants and placed in the overall context of the cartel. That context is provided in leniency statements but because these are written specifically for the purposes of the procedure before a competition authority, their disclosure can at no point in time be ordered. With this in mind, even in situations where a claimant is successful in specifying a concrete piece of pre-existing documents and information, its value will not necessarily be substantial for the claimant. Finally, it should not be forgotten that leniency programmes and settlement procedures were introduced to facilitate the detection and sanctioning of cartels, since they were very difficult to prove in the regular, unassisted procedure (given the lack of material evidence). The same difficulties will apply to private claimants with regard to acquiring pre-existing documents, unless they know exactly what to look for, which will rarely be the cases.

It has been repeatedly stressed that rules on the protection of leniency statements and settlement submissions sought to protect leniency programmes, threatened by Pfleiderer ${ }^{79}$ and Donau Chemie ${ }^{80}$. An extensive academic discussion took place on the potential negative impact of the Pfleiderer balancing test ${ }^{81}$ on the EU leniency programme ${ }^{82}$. Most of the opinions are based around the argument that leniency will be much less attractive for

79 Pfleiderer $A G$ v Bundeskartellamt, C-360/09, EU:C:2011:389.

80 Bundeswettbewerbsbehörde v Donau Chemie AG and Others, C-536/11, EU:C:2013:366.

81 In fact, according to Pfleiderer, Member States' courts should, on the basis of national laws, determine 'conditions under which access must be permitted or refused by weighing the interests protected by the European Union law', Pfleiderer AGv Bundeskartellamt, C-360/09, EU:C:2011:389, para 33.

82 P.J. Slot, 'Does the Pfleiderer judgment make the fight against international cartels more difficult?' (2013) European Competition Law Review 197-206; U. Müller, 'Access to the file of a national competition authority' (2011) 2 European Law Reporter 56-64; A. Geiger, 'The end of the EU cartel leniency programme' (2011) 3 European Competition Law Review 535-536; C. Hummer, M. Cywinski, 'ECJ's judgments in 'EnBW' and 'Donau Chemie' and the unresolved problems of access to the file' (2014) 7(2) Global Competition Litigation Review 115-118; S.B. Völcker, 'Case C-360/09, Pfleiderer AG v. Bundeskartellamt, Judgment of the Court of Justice (Grand Chamber) of 14 June 2011, nyr.', (2012) Common Market Law Review 695-720; G. Goddin, 'The Pfleiderer Judgment on Transparency: The National Sequel of the Access to Document Saga' (2012) 3(1) Journal of European Competition Law \& Practice 40-42; A. Kumar Singh, 'Pfeiderer: Assessing its Impact on the Effectiveness of the European Leniency Programme' (2014) European Competition Law Review 110-123; M. Sanders, E. Jordan, et al., 'Disclosure of leniency materials in follow-on damages actions: striking 'the right balance' between the interests of leniency applicants and private claimants?' (2013) European Competition Law Review 174-182; M. Sánchez Rydelski, 'Antitrust Enforcement: Tensions between Leniency Programmes and Civil Damage Actions - How Immune is a Leniency Applicant? (Pfleiderer 
cartelists given the legal uncertainty regarding the possibility of $3^{\text {rd }}$ parties accessing leniency materials. Furthermore, according to the ruling in Donau Chemie, access to leniency documents may be refused only for overriding public interests reasons relating to the protection of leniency programmes. The Court of Justice stressed here that 'it is only if there is a risk that a given document may actually undermine the public interest relating to the effectiveness of the leniency programme that non-disclosure may be justified'83. Therefore, in these cases, the Court of Justice decided that a plaintiff in a follow-on action for damages could access the leniency documents of a NCA under the discretion of a national judge in preforming the balancing exercise. When it comes to corporate statements and settlement submissions, the Damages Directive 'corrected' the above rulings and left national judges no room of discretion to perform such a balancing exercise. As a result, the Directive effectively renders these judgments obsolete with regard to these two categories of documents ${ }^{84}$.

While this is good news for leniency applicants and the Commission as far as protecting public enforcement of competition rules, and in particular the leniency programme, it is bad news for those who have suffered damages due to illegal cartel behaviour. According to the Damages Directive, the general 'rules on the disclosure of documents other than leniency statements and settlement submissions ensure that injured parties retain sufficient alternative means by which to obtain access to the relevant evidence that they need in order to prepare their actions for damages ${ }^{85}$. However, general rules on disclosure, as liberal and permissive as they may be, cannot sufficiently compensate for the lack of access to leniency documents in cartel cases. This is due to the fact that the EC's sanctioning of cartels relays almost completely on the leniency programme. Coupled with the settlement procedures, there is not much hope for private litigants to obtain evidence to support their claims (following a EC cartel decision) within the framework of the new Damages Directive.

Statistic data shows that the use of settlement and leniency has become the norm in the EC's cartel enforcement practice ${ }^{86}$. Over the past five years,

AG/Bundeskartellamt, ECJ (Grand Chamber), Judgment of 14 June 2011, C-360/09' (2011) 6 European Law Reporter 178-182.

${ }^{83}$ Bundeswettbewerbsbehörde v Donau Chemie AG and Others, C-536/11, EU:C:2013:366, para 48.

${ }^{84} \mathrm{P}$. Bentley, supra note 28 at 281 . The authors argue that judgements are still applicable to white-listed documents (pre-existing information) and grey-listed documents (those under the temporary disclosure ban).

85 Recital 27 of the preamble of the Damages Directive.

${ }^{86}$ M. Barennes, 'The Role of the Settlement Procedure and of the Leniency Program in the European Commission's Fight against Cartels: Some Considerations in Light of the Commission's Practice during the Past Five Years (2010-2014)', (not published yet) presented and prepared for the 4. Petar Šarčević International Scientific Conference: EU Competition 
almost all EU cartel cases that led to an infringement decision started with an immunity application. 'Two percentages are particularly telling in this regard. First, 90 per cent of all the prohibition decisions were adopted after an immunity application was lodged. Second, 100 per cent of the cases that ended in a non-settlement decision started with an immunity application. These figures clearly show the critical role the leniency program plays in the Commission's capacity to trigger an investigation and to adopt a final prohibition decision'87. Likewise, from 2010 to 2015, the settlement procedure 'was used in 60 per cent of the decisions the Commission adopted. Even more representatively, for the year 2014 alone, 80 per cent of the Commission's decisions were "full settlement" or "hybrid" decisions"88.

This data is very telling. It means that the Commission no longer renders any cartel decisions within a regular procedure. Consequently, if this enforcement trend continues, there will be no cartel cases where the general, more permissive rules on the disclosure of evidence will be applicable. Furthermore, as already explained, there is not much value to published cartel decisions (in particular settlement decisions) as they contain a very small amount of information of use to a potential plaintiff. Given this fact, and the available statistical data, it may be concluded that the new rules on access to documents will leave private litigants who have suffered damages because of a cartel with a very limited possibility to prove their case before the court if it is the EC that gas rendered the infringement decision. Therefore, despite the general preposition favouring access entrenched in the new Damages Directive, the system will almost certainly continue to favour public over private enforcement (leniency programmes and settlement procedures) regardless of any possible statements to the contrary ${ }^{89}$. However, the outcome may be different when Article 101 TFEU is applied against a cartel by a NCA in jurisdictions that do not have a functioning leniency programme, such as Croatia.

And State Aid Rules: Interaction Between Public And Private Enforcement, Rovinj, 9-10 April 2015, 8 .

87 Statistic data available on the EC website and processed in ibidem.

88 Ibidem.

89 Some voiced the concern that not even this is enough to protect leniency programmes. According to Geradin and Grelier, the principles set by the EC leave sensitive materials largely unprotected in particular the leniency applicants' responses that would be accessible to potential claimants after the investigation ends. Leniency applicants might thus become less forthcoming in their responses; more generally, this could deter prospective applicants. See D. Geradin, L.-A. Grelier, 'Protection of leniency submissions: an insufficient 'Pfleiderer fix' Cartel Damages Claims in the European Union: Have we only Seen the Tip of the Iceberg?' George Mason University School of Law; Tilburg University - Tilburg Law and Economics Centre (TILEC) 2013, available at http://papers.ssrn.com/sol3/papers.cfm?abstract_id $=2362386 \&$ rec $=1 \&$ srcab $\mathrm{s}=2292575 \& \mathrm{alg}=1 \& \operatorname{pos}=1($ accessed 22.05 .2015$)$. 


\section{Access to documents and information in antitrust litigation under Croatian law}

There is only one provision in the Croatian Competition Act regulating private enforcement of competition rules. However, this provision does not grant any specific rights to victims to get access to documents held in the files of the Croatian Competition Agency (hereafter, CCA) with a view of bringing an antitrust damages claim ${ }^{90}$.

According to the general rules of the Civil Procedure Act, in proceedings before the court, each party is obliged to provide facts and present evidence on which his claim is based ${ }^{91}$. It is the court that subsequently decides which of the proposed evidence shall be presented to establish the decisive facts ${ }^{92}$. It is up to the party to furnish the documents representing proof of his statement. If such documents are in the possession of a state authority, or a $3^{\text {rd }}$ person ${ }^{93}$, and the party him is not able to arrange for the document to be handed over or shown, the court shall obtain the document by itself upon a motion by the party ${ }^{94}$. However, the court will intervene only when the requesting party specifies concrete pieces of evidence. Under the Croatian normative

90 Art. 69a defines commercial courts as competent to decide on damages claims based on the infringements of Croatian and EU competition rules. It further establishes the liability of undertakings concerned for the compensation for damages resulting from competition law infringements. Although the decisions of the CCA are not legally binding for commercial courts, according to Art. 69a, they must take into account the legally valid decision of the CCA on the basis of which an infringement of domestic or EU competition rules has been established. Likewise, competent commercial courts must take account of final decisions of the EC in cases where the EC established the infringement of Article 101 or 102 TFEU. The competent commercial court may assess whether it is necessary to stay or suspend its proceedings until a legally valid decision of the CCA or a final decision of the EC is rendered. Furthermore, the competent commercial court must inform the CCA of any claims filed regarding the right to seek compensation for antitrust damages based on EU or domestic competition rules. The limitation period for damages claims should be suspended from the day on which the proceeding was initiated by the CCA or by the EC until the day when the relevant proceedings have been closed.

91 Art. 219 of the Civil Procedure Act, official gazette Narodne novine 53/91, 91/92, 58/93, 112/99, 88/01, 117/03, 88/05, 02/07, 84/08, 123/08, 57/11, 148/11, 25/13, 89/14.

92 Art. 220(2) of the Civil Procedure Act.

93 [and] the party him/herself is not able to arrange for the document to be handed over or shown.

94 Art. 232-233 of the Civil Procedure Act. When one party refers to a document and claims that it is in the possession of the other party, the court shall order the latter to furnish the document, giving him/her a time limit to do so. The court, in view of all the circumstances and according to its conviction, shall assess the significance of the fact that the party who has possession of the document refuses to act according to the court ruling ordering him/her to furnish the document or, contrary to the conviction of the court, denies that the document is in his/her possession. 
set-up, the parties should know exactly what the documents are that have to be presented in support of their claim, and should try to obtain them by themselves before requesting a court order. Potential plaintiffs may opt for two routes to obtain such documents: via the Competition Act or via the Act on the right of access to public information, both routes being of very limited value for gathering evidence.

\section{Access under the Competition Act}

The Croatian Competition Act only contains a provision on access to documents for the purposes of proceedings held before the Croatian NCA - the CCA. In that sense, quite logically, the right to full access to the files of the CCA is granted only to the parties to such proceedings, and only after they received a Statement of Objections ${ }^{95}$. Although the scope of disclosure is rather wide, some categories of documents cannot be accessed even by the parties. They include: draft decision, official statements, protocols and typescripts from the sessions of the Council, internal instructions and notes on the case, correspondence and information exchanged between the CCA and the EC, between the CCA and other international competition authorities and their networks, and other documents which are covered by the obligation of business secrecy ${ }^{96}$. All other documents may be accessed during or after the procedure.

Substantially more limited access to the CCA's file is granted to two other categories of persons: those who filed the initiative for the commencement of public proceedings, and those who find that their rights or legal interests are decided upon by the CCA. According to Article 36(2) of the Croatia Competition Act, a person who filed the initiative for the commencement of public proceedings is not a party to the proceedings. He may, however, be granted certain procedural rights. Similarly, those whose rights or legal interests are decided upon by the CCA are not parties to the proceedings, but they may be granted the same procedural rights as the person who initiated the proceedings ${ }^{97}$. Both of these types of entities are likely plaintiffs in antitrust damages claim. Hence, these rules are of particular importance when it comes to access to documents for the purposes of antitrust damages claims. Pursuant to the Croatian Competition Act, during public enforcement proceedings, the above categories of entities may only be granted access to a non-confidential,

\footnotetext{
95 Art. 47(1) of the Croatian Competition Act, official gazette Narodne Novine 79/09, 80/13.

96 Art. 47(4) of the Croatian Competition Act.

97 Art. 36(3) of the Croatian Competition Act.
} 
shortened version of the Statement of Objections ${ }^{98}$. Once the proceedings are over and the decision is rendered, the right of access is granted only if the CCA refuses to open proceedings or fails to find a violation of the Croatian Competition Act ${ }^{99}$. Very rightly, some authors have observed that this 'normative set-up presupposes that it is not necessary to grant the right to access to file for those harmed by an antitrust infringement in cases where the agency adopts a decision finding the infringement ${ }^{\prime}{ }^{100}$. At the same time, in terms of private antitrust damages claims, these are the most important rules. The legislator's intention was clearly limited only to regulating the public enforcement procedure conducted before the CCA and so $3^{\text {rd }}$ parties have a very narrow scope for accessing potential evidence via the Croatian Competition Act ${ }^{101}$.

Analogue to EC infringement decisions, $3^{\text {rd }}$ parties may actually try to rely on the information provided in published decisions. Yet the above discussion on the value of such decisions, and the time necessary for their publication in the EU context, is applicable domestically as well, albeit to a lesser degree. This refers to the publication of non-confidential versions of CCA decisions with a limited evidentiary value, the publication of which may be delayed by the interplay between the parties and the CCA on what constitutes business secrets (although such delay rarely happens). In principle, the CCA considers that the data and documentation on which its decision is based is normally not covered by its duty to protect business secrecy ${ }^{102}$. However, the Croatian Competition Act provides also that the notion of business secrets covers everything which is defined to be a business secret by the undertaking concerned, if accepted as such by the $\mathrm{CCA}^{103}$.

From all the decisions published on the CCA website since 2010, there has been only one regarding a request to access documents on the grounds of the Croatian Competition Act by the person who filed the initiative for the

98 Art. 47(6) and 48(4) of the Croatian Competition Act.

99 According to Art. 47(5) of the Croatian Competition Act, 'the person who filed the initiative and the persons who, based on the separate decision of the CCA, have been granted the same procedural rights which are enjoyed by the person who filed the initiative, shall enjoy the right of access to the documents which served as a basis for the decision of the CCA as follows: after the receipt of the decision referred to in Article 38 of this Act stating the reasons on the basis of which there was no public interest or no grounds for the initiation of the proceedings, after the receipt of the decision'.

100 J. Pecotić Kaufman, 'How to facilitate damages claims? Private enforcement of competition rules in Croatia- Domestic and EU Law perspective' (2012) 5(7) Yearbook of Antitrust and Regulatory Studies 14-54.

101 This issue has not been decided by the courts yet, so it remains to be seen 'what position the courts will take in determining the interests of the complainant and whistle-blowers'; B. Vrcek, 'Developments in private enforcement of competition rules after the Croatian accession to the EU' (2014) 7(3) Global Competition Litigation Review 155.

102 Art. 53(6) point 4 of the Croatian Competition Act.

103 Art. 53(2) point 3 of the Croatian Competition Act. 
commencement of the proceeding. The request aiming to access particular pieces of documentation was eventually denied by the CCA on the grounds of their confidentiality (business secrets ${ }^{104}$ ). There may be many more decisions of this kind - they are simply rarely published due to their relative unimportance for the wider public. For that reason, it is difficult to make an empiric analysis. However, judging from the rules themselves, it may easily be concluded that access by $3^{\text {rd }}$ parties via the Croatian Competition Act is very restrictive.

\section{Access under the Act on the right of access to information}

Because of such a limited possibility of document access through the Croatian Competition Act, $3^{\text {rd }}$ parties (potential plaintiffs who wish to access the CCA's file) would currently have to rely on the general rules of the Act on the right of access to information ${ }^{105}$ (hereafter, Act on Access to Information). The latter is the national equivalent of the Transparency Regulation and is compliant with the latter ${ }^{106}$. The objective of the Act on Access to Information is to give natural persons and legal entities the possibility to exercise the right of access to information, as well as its re-use. However, similarly to the Transparency Regulation, the Act on Access to Information restricts the right of access under certain circumstances.

A temporary access ban applies to information relating to any procedures held by the competent bodies in their preliminary and investigation activities - this ban applies for the duration of the respective procedures ${ }^{107}$. In those cases, the relevant public body must deny access. All other restrictions are discretionary. According to Article 15(2) of the Act on Access to Information, public authorities may restrict access if, inter alia, the information represents a trade or professional secret under the law ${ }^{108}$, and if the information is generated by public authority bodies, and if disclosure prior to completion of its final version might seriously undermine the decision-making process ${ }^{109}$. Of course, the latter relates to situations where access is requested prior to the completion of the final version of the relevant document. Finally, public authorities may restrict access to information in the case of a reasonable doubt that such disclosure might prevent the conduct of efficient, independent and unbiased judicial,

104 UP/I 034-03/2014-01/016 from 30.07.2014.

105 Act on the right of access to information, official gazette, Narodne Novine 25/13 (hereafter, Act on Access to Information).

106 Art. 3 of the Act on Access to Information.

107 Art. 15(1) of the Act on Access to Information.

108 Art. 15(2) point 2 of the Act on Access to Information.

109 Art. 15(2) point 5 of the Act on Access to Information. 
administrative or other legally regulated proceedings ${ }^{110}$, and the execution of court orders or sentences, and prevent the work of bodies conducting administrative supervision, inspectional supervision (legal supervision) ${ }^{111}$.

In applying this discretionary right, the relevant authority is bound to conduct the proportionality test and the public interest test prior to reaching its decision. The two tests refer to the assessment of the proportionality between reasons for disclosure and reasons for imposing access restrictions, and granting access to information only if the public interest prevails ${ }^{112}$. More specifically, the test consists of whether granting access to the requested information in each individual case would seriously damage these interests, and whether the need to protect the right to confidentiality prevails over the public interest. If the public interest prevails over the damage caused to individual interests, the information shall be made available ${ }^{113}$. Under the normative intention of the legislator, public interest consists of disclosure, while the protection of documents reflects, in effect, the protection of the private interest of the person to whom the information relates. However, the debate over protecting leniency statements reverses the above notion of public and private interest. Protection of documents equates here to the protection of the public interest, while disclosure equates to the protection of the individual interest of the particular plaintiff in a civil action for damages. In that sense, it becomes rather difficult, if not impossible, to properly perform the proportionality and public interest tests while deciding whether to grant the disclosure request of documents contained in the CCA's file, as proscribed by the Act on the right of access to information. Even though this is a very important issue for actions for damages, it is not possible to make any empirical conclusions here, as there are no publicly available decisions that would demonstrate in what manner the CCA decides on such requests. This is not surprising considering that there are hardly any antitrust damages cases pending before commercial courts in Croatia, so no evidence is being gathered for that purposes.

\section{Possibilities and pitfalls of the pending implementation of the Damages Directive}

The implementation of the Damages Directive into Croatian legislation, including rules on disclosure contained in its Articles 5 and 6, will inevitably affect the approach to access to documents by potential claimants. National

\footnotetext{
110 Art. 15(3) point 1 of the Act on Access to Information.

111 Art. 15(3) point 2 of the Act on Access to Information.

112 Art. 5(7) of the Act on Access to Information.

113 Art. 16(2) of the Act on Access to Information.
} 
rules will have to be adapted and it is suggested here that this should be done for competition cases only, and within the ambit of the Civil Procedure Act. Some of the rules of the Damages Directive are more relaxed for plaintiffs than current Croatian solutions. Such is the case with Article 5(2) of the Damages Directive whereby Member States must ensure that national courts are able to order the disclosure of specified items of evidence or 'relevant categories of evidence', circumscribed as precisely and as narrowly as possible on the basis of reasonably available facts in the reasoned justification. The current text of the Croatian Civil Procedure Act contemplates however only court assistance in obtaining concrete documents. When transposed, the EU solution might greatly relax the position of plaintiffs in Croatian court proceedings. The position of plaintiffs might also become more favourable in Croatia following the implementation of the Directive's rule explicitly granting to national judges the power to order documents containing confidential information, against a guarantee of their safety. According to Croatia's current normative set-up, it is not clear whether a national judge would have such an explicit power, or it would be up to the CCA to decide on the deliverable content of a document.

On the other hand, by being much more specific regarding requirements placed on the national judiciary, Articles 5 and 6 of the Damages Directive might also have a narrowing down effect when it comes to the rights of private claimants. Under the current normative set-up, a Croatian judge is bound to evaluate only the relevance of the documents in terms of their value in establishing the facts of the case. Following the implementation of the Damages Directive, this situation will inevitably change placing the judge in a position of a protector of the effectiveness of public enforcement of competition law. Yet looking from a different perspective, the requirements of the proportionality test as defined by the Directive might give valuable guidance to Croatian judges (which are generally not overly keen to give lengthy explanations for their decisions). The rights of claimants in Croatia might also be narrowed down following the implementation of the Directive because of its rule whereby a national court may order the disclosure of evidence included in the file of a competition authority only where no party, or $3^{\text {rd }}$ party, is reasonably able to provide that evidence. There is no such rule currently in operation in Croatia.

Certainly, the rule on the absolute protection of leniency applications contained in Article 6 of the Damages Directive is completely novel to the Croatian normative-set up (rules on settlement submissions are irrelevant in this context because no such procedure exists in Croatia). Although current legislation does not contain such rule in relation to a civil damages action, the CCA would most probably protect these documents against disclosure on the ground of Article 7 of the Regulation on immunity from fines and 
reduction of fines ${ }^{114}$. On its basis, leniency statements may be disclosed only to parties to the proceedings before the CCA, and only after they have received their Statement of Objections. Disclosure may be granted exclusively for the purposes of the procedure before the CCA, or before the Administrative Court as a $2^{\text {nd }}$ instance body. Being very explicit and restrictive, these rules would justify the CCA's decision against a $3^{\text {rd }}$ party disclosure request.

What comes to mind is that these specific rules on private enforcement facilitating the position of the claimant, and in particular rules on access to documents, might actually prove to be very valuable in the Croatian context. Actually, the entire debate on the balance between public and private enforcement is likely to have a completely different dynamics in Member States with underdeveloped public enforcement. For instance, not a single leniency application has so far been lodged in Croatia, despite the fact that it has already been 5 years since Croatia's Leniency programme was introduced (2010) with the adoption of the Regulation on the method of setting fines ${ }^{115}$ and the Regulation on immunity from fines and reduction of fines. It is very difficult to identify the reasons behind the failure of the domestic programme, considering EU cartel enforcement relies almost completely on its leniency. The most logical conclusion here would be the infringers' perception that the CCA is unable to detect and punish cartels on its own. Wills very rightfully observes that 'a leniency policy will [...] start working if the antitrust enforcement authority concerned has built up a sufficient level of credibility as to its capacity to detect and punish antitrust violations on its own'116.

If one is to look over Croatian cartel enforcement, a few facts stand up. Over the past five years, the CCA rendered two cartel decisions a year on average. Yet the imposed fines have rarely been serious enough to act as a deterrent against such behaviours in the future. In fact, most of the cartel decisions ended up with symbolic fines only, including the most recent 'marinas' 117 and 'orthodontists' ${ }^{118}$ cartels ${ }^{119}$. With this in mind, there is hardly any incentive for cartelists to apply for immunity in Croatia. Hence, the CCA has set as one of its priorities the promotion and the presentation of the immunity programme in cartel cases $^{120}$.

114 Regulation on immunity from fines and reduction of fines, official gazette Narodne novine 129/2010; 23/2015 (hereafter, Leniency regulation).

115 Ibidem.

116 Art. 7 of the Leniency regulation.

117 Decision UP/I 034-03/2013-01/047, from 17.03.2015.

118 Decision UP/I 034-03/13-01/034, from 12.06.2014.

119 With the exception of the recent personal protection cartel where the CCA fined the seven undertakings with a total of 5 billion Kunas.

120 The priorities of the work of the CCA in the forthcoming period are laid down in its strategy statement for 2014-2016. 'Promoting the benefits of effective competition produces 
Secondly, the CCA has not been maximising the use of the powers that have been entrusted to it. For instance, CCA has been empowered to carry out dawn raids since the 2009 Competition Act and yet its first dawn raid has not occurred until 2013 and they have rarely been used since ${ }^{121}$. The efforts of the CCA, particularly dawn raids, were constrained by the lack of computer forensics equipment, which is indispensable for gathering evidence in cartel cases $^{122}$. Without such equipment, potential infringers may easily hide and/ or destroy evidence ${ }^{123}$. This situation has changed recently with the purchase of state of the art digital forensic equipment. This new technical support is expected to enhance the CCA's powers to directly collect evidence during dawn raids, which may now be performed simultaneously on different sites ${ }^{124}$. Since the above investment in forensic equipment is very recent, it is to be seen whether it will indeed live up to expectations, enhance the CCA's actual powers and, in turn, its credibility in the eyes of infringers.

Finally, it appears that a substantial number of undertakings in Croatia are still unaware of the illegality of cartel agreements. The 'personal protection security services' cartel ${ }^{125}$ is one of very recent examples. The cartel was detected by the CCA while surfing the web page of a specialized domestic magazine Zaštita (in English: Protection). A press release was found therein about a meeting during which personal protection agencies agreed upon minimum prices for personal protection security services (amounting to 32.52 Kuna per hour, equivalent to EUR 4,34). This case shows that Croatia suffers from an insufficient competition culture and awareness of the positive national and European legal framework.

Like in any other jurisdictions, there are undertakings in Croatia that engage in cartels, and yet no one is yet interested in participating in the domestic leniency programme. It is certainly very important to continue building up the institutional capacity of the CCA and to show the public its credibility to deter

for undertakings and consumers will stay in the focus of the CCA, concentrating on most harmful practices for both consumers and other competitors, that is, hard core restrictions of competition and particularly cartels' (Competition report 2013 available at www.aztn.hr, accessed 30.05.2015).

121 However, on that particular occasion evidence on the existence of a cartel was not found. See Annual Report of the CCA for 2013. Available at http:/www.aztn.hr/uploads/documents/ eng/documents/AR/Annual_Report_of_the_Croatian_Competition_Agency_for_2013.pdf (accessed 10.06.2015).

122 AZTN Info, 3 March 2015.

$123[\ldots]$ and limited budgetary resources for the purchase of such equipment (Competition report 2013 available at www.aztn.hr accessed on 15.06.2015).

124 Annual Report of the CCA for 2014, available at http://www.aztn.hr/ea/wp-content/ uploads/2015/05/GI-AZTN-2014.pdf (accessed 31.08.2015), p. 38.

125 Decision UP/I 034-03/14-01/002, from 17.03.2015. 
and punish cartels. However, it will be very interesting to see whether private enforcement may actually boost public enforcement thanks to the use of the new rules on access to documents. In fact, the rules on access to documents entrenched in the Damages Directive might actually work in favour of private litigants in countries like Croatia, where all cartel decisions are rendered in regular procedures, as rules on access in regular procedures are wide, specific, and available for access to the entire spectrum of valuable documents. This availability of documents gathered through ordinary procedures might in turn motivate private claimants to bring civil suits. It can also incentivise potential infringers to apply for leniency in order to protect evidence from their potential use in civil lawsuits. However, it will take time to see the actual effects of the Damages Directive once implemented into national legislation.

\section{Conclusions}

The purpose of this paper was to analyse the possible effects of the rules on access to evidence prescribed by the Damages Directive on future private enforcement. To that end, the existing EU legislative framework and case law has been scrutinised. It was argued that rules on access to documents might have a chilling effect on private litigants when it comes to cartel decisions rendered by the Commission. This is due to the introduction by the Directive of an absolute ban on the disclosure of leniency statements and settlement submissions though a 'maximum harmonization' rule. This conclusion is drawn from statistic figures showing that EU cartel enforcement entirely rests on those procedures. With that in mind, it may be stated that general rules on access to documents (other than leniency and settlement procedures) are not a sufficient means for private plaintiffs to obtain evidence necessary to prove their case.

However, the Directive's new rules on access to documents may have an opposite impact on private enforcement in cases following an infringement decision issued by a NCA when the latter does not rely as much as the EU on leniency programmes. In jurisdictions such as Croatia where all cartel decisions so far have been rendered within the regular procedure, general access to documents will apply. It is argued that such rules, coupled with other rules facilitating the position of the claimant in antitrust damages proceedings, might actually be beneficial for both public and private enforcement. 


\section{Literature}

Barennes M., 'The Role of the Settlement Procedure and of the Leniency Program in the European Commission's Fight against Cartels: Some Considerations in Light of the Commission's Practice during the Past Five Years (2010-2014)', (not published yet) presented and prepared for the 4. Petar Šarčević International Scientific Conference: EU Competition And State Aid Rules: Interaction Between Public And Private Enforcement, Rovinj, 9-10 April 2015.

Bentley P., Henry D., 'Antitrust Damages Actions: Obtaining Probative Evidence In The Hands Of Another Party' (2014) 37(3) World Competition.

Blume Huttenlauch A., 'Transparency (Un)limited?' (2014) European Law Reporter.

Brömmelmeyer C., 'Directive damages: Does the Commission overstep the marks again?' (2015) 1 Sorbonne Procedural Law Review Online, http://irjs.univ-paris1.fr/ labo/departement-de-recherche-justice-et-proces/revuelectroniqueliensprocessu/ directiveprivateenforcement/.

Bukovac Puvača M., Butorac V., 'Izvanugovorna odgovornost za štetu prouzročenu povredom pravila tržišnog natjecanja' (2008) 6 Zbornik radova Pravnog fakulteta Sveučilišta u Mostaru.

Chirita A., 'The disclosure of evidence under the Directive 2014/104/EU', (not published yet) presented and prepared for the 4. Petar Šarčević International Scientific Conference: EU Competition And State Aid Rules: Interaction Between Public And Private Enforcement, Rovinj, 9-10 April 2015.

Gavil I.A. 'The Challenges of economic proof in a decentralized and privatized European competition policy system: lessons from the American experience' (2008) 4(1) Journal of Competition Law and Economics.

Geiger A., 'The end of the EU cartel leniency programme' (2011) 32(10) European Competition Law Review.

Geradin D., Grelier L.-A., 'Protection of leniency submissions: an insufficient 'Pfleiderer fix' Cartel Damages Claims in the European Union: Have we only Seen the Tip of the Iceberg?', George Mason University School of Law; Tilburg University - Tilburg Law and Economics Centre (TILEC) 2013, http://papers.ssrn.com/sol3/papers.cfm?abstract_ $\mathrm{id}=2362386 \& \mathrm{rec}=1 \& \mathrm{srcabs}=2292575 \& \mathrm{alg}=1 \& \mathrm{pos}=1$

Goddin G., 'The Pfleiderer Judgment on Transparency: The National Sequel of the Access to Document Saga' (2012) 3(1) Journal of European Competition Law \& Practice.

Gutierrez-Rodriguez J.D., 'Expert Economic Testimony In Antitrust Cases: A Comparative Law And Economic Study' (2009) 14 International Law, Revista Colombiana De Derecho Internacional.

Howard A., 'Disclosure Of Infringement Decisions In Competition Damages Proceedings: How The UK Courts Are Leading The Way Ahead Of The Damages Directive' (2015) 6(4) Journal of European Competition Law \& Practice.

Howard A., 'The Draft Directive On Competition Law Damages- What Does It Mean For Infringers And Victims?' (2014) 35(2) European Competition Law Review.

Hummer C., Cywinski M., 'ECJ's Judgements In "Enbw" And "Donau Chemie" And The Unresolved Problems Of Access To File' (2014) 7(2) Global Competition Litigation Review.

Kellerbauer M., 'The Recent Case Law On The Disclosure Of Information Regarding EU Competition Law Infringements To Private Damages Claimants' (2014) 35(2) European Competition Law Review. 
Kumar Singh A., 'Pfleiderer: Assessing its Impact on the Effectiveness of the European Leniency Programme' (2014) European Competition Law Review.

Jones C.A., 'Private Antitrust Enforcement in Europe: A policy Analysis and Reality Check' (2004) 27(1) World competition.

Lacchi C., Östlund A., 'General Presumptions of Non-disclosure of Leniency Documents: a New Approach to the Interaction between Public and Private Enforcement of Antitrust Law?' (2014) European Law Reporter.

Lebrun B., Bersou L., 'Commission v EnBWEnergie: Non-Disclosure of Leniency Documents' (2014) 5(7) Journal of European Competition Law \& Practice.

Mackenzie G., 'The public now enjoys partial access to the EC's file in cartel cases' (2005) 4(9) Competition Law Insight.

Mario M., 'Private litigation as a key complement to public enforcement of competition rules and the first conclusions on the implementation of the new Merger Regulation', SPEECH/04/403.

Müller U., 'Access to the file of a national competition authority' (2011) 2 European Law Reporter.

Pecotić Kaufman J., 'How to facilitate damages claims? Private enforcement of competition rules in Croatia - Domestic and EU Law perspective' (2012) 5(7) Yearbook of Antitrust and Regulatory Studies.

Roth P., Rose V. (eds.), Bellamy \& Child, European Community Law of Competition, 6th ed., Oxford University Press 2008.

Sánchez Rydelski M., 'Antitrust Enforcement: Tensions between Leniency Programmes and Civil Damage Actions - How Immune is a Leniency Applicant? (Pfleiderer AG/ Bundeskartellamt, ECJ (Grand Chamber), Judgment of 14 June 2011, C-360/09' (2011) 6 European Law Reporter.

Sanders M., Jordan E., et al., 'Disclosure of leniency materials in follow-on damages actions: striking 'the right balance' between the interests of leniency applicants and private claimants?' (2013) European Competition Law Review.

Slot P.J., 'Does the Pfleiderer judgment make the fight against international cartels more difficult?' (2013) European Competition Law Review.

Stefano G., 'Access of damage claimants to evidence arising out of EU cartel investigations; a fast evolving scenario' (2012) 5(3) Global Competition Litigation Review.

Völcker S.B., 'Case C-360/09, Pfleiderer AG v. Bundeskartellamt, Judgment of the Court of Justice (Grand Chamber) of 14 June 2011, nyr.' (2012) Common Market Law Review.

Vrcek B., 'Development sin private enforcement of competition rules after the Croatian accession to the EU' (2014) 7(3) Global Competition Litigation Review.

Walle S.V., Private Antitrust Litigation in the European Union and Japan: A Comparative Perspective, Maklu, Antwerpen-Apeldoorn 2013.

Wils P.J.W., 'Should private antitrust enforcement be encouraged in Europe?' (2003) 26(3) World Competition. 